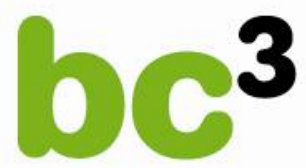

BASQUE CENTRE

FOR CLIMATE CHANGE

Klima Aldaketa Ikergai

\title{
Long Run Trends in
}

\section{Energy-Related External Costs}

\author{
Roger Fouquet
}

January 2011

BC3 WORKING PAPER SERIES

2011-01 
The Basque Centre for Climate Change (BC3) is a Research Centre based in the Basque Country, which aims at contributing to long-term research on the causes and consequences of Climate Change in order to foster the creation of knowledge in this multidisciplinary science.

The BC3 promotes a highly-qualified team of researchers with the primary objective of achieving excellence in research, training and dissemination. The Scientific Plan of BC3 is led by the Scientific Director, Prof. Anil Markandya.

The core research avenues are:

- Adaptation to and the impacts of climate change

- Measures to mitigate the amount of climate change experienced

- International Dimensions of Climate Policy

- Developing and supporting research that informs climate policy in the Basque Country

See www.bc3research.org for further details.

The BC3 Working Paper Series is available on the internet at http://www.bc3research.org/lits_publications.html

Enquiries (Regarding the BC3 Working Paper Series):

Roger Fouquet

Email: roger.fouquet@bc3research.org

www.bc3research.org

The opinions expressed in this working paper do not necessarily reflect the position of Basque Centre for Climate Change (BC3) as a whole.

Note: If printed, please remember to print on both sides. Also, perhaps try two pages on one side. 


\title{
Long Run Dynamics of Energy-Related External Costs
}

\author{
Roger Fouquet ${ }^{12}$
}

This paper considers how energy-related external costs change through time. It focuses on one of the key periods in the history of energy. After a period of declining coal prices and soaring consumption which fuelled the Second Industrial Revolution, the nineteenth century British economy was externalising the social costs of energy production and consumption on a massive scale. Rising from $25 \%$ in the 1820 s, an estimated $60 \%-70 \%$ of the average social costs of coal were externalised in the 1880s, imposing damages close to $20 \%$ of GDP. The eventual decline in air pollution concentration (around 1900) occurred fifty years later than was broadly socially optimal. This experience highlights the evolution of the demand for and supply of environmental quality in the context of economic growth, and the nature of related market and government failures, implying the necessity for adaptation rather than encouraging mitigation. This experience may offer lessons for climate analysis and policy-making.

Keywords: External costs; Energy; Coal; Historical; Long Run; Air Pollution.

JEL Classification: Q41, Q43, Q51, Q53, N53, N83

Cite as: Fouquet, R. (2011) Long Run Trends in Energy-Related External Costs. BC3 Working Paper Series 2011-01. Basque Centre for Climate Change (BC3). Bilbao, Spain.

\footnotetext{
${ }^{1}$ Basque Centre for Climate Change (BC3). Alameda Urquijo, 4 - 4॰ 48008 Bilbao, Spain; and IKERBASQUE, Basque Foundation for Science. Alameda Urquijo 36-5, 48011 Bilbao, Spain.

Corresponding author E-mail: roger.fouquet@bc3research.org.

${ }^{2}$ I am grateful to Anil Markandya, Elena Ojea, Tanya O’Garra, Thomas Sterner, and two anonymous referees for comments related to this research.
} 


\section{Introduction}

Economic growth can provide huge improvements in material well-being, while imposing a large burden on the environment and society (Mishan 1967). The large Environmental Kuznets Curve (EKC) literature has offered considerable empirical evidence on the relationship between economic growth and environmental pollution (Carson 2010). Implicit in much of the EKC debate is the view that environmental damage is just the price to pay at early stages of economic development - first, economies need to grow, in an environmentally damaging way, leaving markets and society to adapt to the damage, and, only later, clean-up. Yet, despite Mishan's (1967) study, the damages have rarely been quantified (Jones 2011).

Traditionally, external costs have been measured at a point-in-time. The vast literature driven by ExternE was built upon attempts to capture the current value of energy or transport systems (Krewitt 2002, Bickel and Friedrich 2005). More recently, however, studies of the impact of climate change have developed scenarios in which these future damages are likely to vary considerably through time (Tol 2002). After all, models of the impacts study periods of more than fifty years during which the global economy may grow considerably and be radically transformed (Nordhaus 2008). Indeed, a better understanding of the long run trends in the cost to and value of environmental resources will be central to prescribing climate policies (Sterner and Persson 2008). Yet, perhaps, because the valuation of present and future external costs has been driven by policy recommendations, their valuation has drawn little from past long run experiences.

So, while the EKC literature has tended to be backward-facing, learning from past empirical evidence, studies of external costs have been looking at the present and the future. This paper proposes that there may be benefits from looking at the past trends in external costs. In doing so, the author hopes to provide a different perspective both on external costs and on the relationship between economic growth and its burden on the environment and society. Such a perspective may be useful for explaining economic behaviour related to energy use, anticipating future environmental damage and offering policy recommendations.

The purpose of this paper is, therefore, to begin to understand how external costs have changed through time. It could be seen as 'a monetisation of the EKC'. However, by estimating the external costs, it identifies market and government failures, and also helps to provide a more structural analysis of the relationship between economic growth and environmental quality.

To do so, this paper focuses on one of the most important periods in the history of energy, the expansion of coal use in nineteenth century Britain, which fuelled the Second Industrial Revolution. The story has been recounted before, either as an industry (Flinn 1984, Church 1986), as the diver of economic growth (Landes 1969, Allen 2009) and as a source of pollution (Brimblecombe 1987, Mosley 2001, Clay and Troesken 2010). However, the trade-offs between private individuals 
and society have not been considered directly. Here, the results identify a case of very high external costs that raise questions about future trends in environmental damages.

This paper is structured as follows. The first section provides a brief review of how external costs might be expected to trend. Then, estimates of the damages associated with coal production and consumption are presented. They focus exclusively on the rise and then decline in deaths from coal mining accidents and respiratory diseases, and especially from local air pollution. Afterwards, trends in the value of a statistical life and of a life year lost are explained. These provide the basis for the estimates of the external costs, and comparing them to trends in prices. The benefits and costs of coal production and consumption are compared, and the market and government failures discussed. The final section draws conclusions.

\section{Expected Trends in Total and Marginal External Costs}

This section discusses how external costs might be expected to vary through time. This can be broken down into two parts: the overall level of pollution through time and marginal external costs per unit of pollution. Here, the purpose is not to delve deeply into the theory of pollution and damage functions, but only to build a bridge between the theory and empirical evidence on external costs.

The most basic assumption (known as the scale effect) is that a growth in population and economic activity leads to a greater use of resources and environmental damage (Meadows et al 1972). The extensive EKC literature has studied the relationship between per capita income and environmental damage, and proposes that, initially, as economies grow, they do impose an increasingly large burden on the environment, but that, beyond a turning-point, they are able to grow while reducing their damage (Grossman and Krueger 1995, Panayotou 1997). The analysis of certain pollutants (e.g. sulphur dioxide) in certain countries does support tentatively the existence of this relationship (Selden and Song 1992, List and Gallet 1993, Dinda 2004). However, the existence of causal mechanisms has not been shown empirically, the statistical analyses have frequently been criticised and believing that the EKC is a formal relationship could be dangerous if it forms the basis for developing environmental policies (Stern 2004).

One way to consider the trends in pollution is as the outcome of the changing dynamics of the demand for and the supply of environmental quality (Pearson 1994, Kolstad 2006). The supply includes factors that may worsen or improve the level of pollutant emissions and the ability of waste receptors to deal with these emissions. These factors may change either exogenously or endogenously. In the latter case, supply may adjust in response to signals by the demand - either directly to public demands or, most probably (given the tendency to free ride), indirectly through government policies, legislation and enforcement, which in some way reflect demands for environmental quality. As a tool for analysing the relationship between income and environmental damage, the explanations for (and against) the EKC can be placed within this structural model of supply and demand (Carson 2010). 
On the supply-side, first, economic development is associated with a shift from agriculture to heavy and then light industry, and possibly to commerce and services. Each of these sectors has different environmental damages - for instance, agrarian societies radically alter land use and natural habitats, while heavy industry requires intensive mining and heating (provided cheaply by fossil fuels) to transform materials (Mosley 2010). Second, for certain activities, such as those associated with energy use, there tend to be transitions in resources used (e.g. from biomass to coal to petroleum to gas). These transitions may also, coincidently, have a lower or higher impact on the environment (Fouquet 2010). Third, polluters (whether individual agents, cities or countries) can export their emissions, either to uninhabited or poorer areas and countries; this is a broader version of the 'pollution haven' hypothesis (Cole 2004). These last two factors can be seen as the result of exogenous forces (such as energy transitions or the introduction of a free trade agreement) or in response to environmental concerns and legislation. Fourth, as more 'cleaner' technology is produced and used, unit costs may fall. If increasing returns to scale do exist, wealthier countries, because of greater investment in pollution abatement, can reduce emissions more cheaply (Andreoni and Levinson 2001). It also suggests that, at the same stage of economic development, current developing economies might also have access to cheaper abatement technologies than today's developed economies.

On the demand-side, first, as income rises, households have more time and money to be concerned about the environment - that is, there is a 'positive' income elasticity for the environment. Second, although there is limited evidence of this, as income rises, households may be more concerned and interested in the environment - a 'greater than one' income elasticity for the environment (Dorfman 1977). Third, possibly helping to justify that last statement, communities with higher incomes tend to have a greater awareness, information, education and knowledge of environmental pollution, risks and hazards. This often drives the introduction of more stringent environmental legislation (Dasgupta et al 2002, Kahn 2002). Fourth, more open and democratic political systems should be more willing to reflect the concerns and sufferings of the public (López and Mitra 2000).

So, factors may exist which shift the demand and supply towards generating a pollution outcome that follows an inverse-U path. On the other hand, if those factors do not prevail (e.g. global pollutants, which imply that exporting does not dissipate the problem (Kolstad 2006); decreasing returns to scale in abatement technology (Andreoni and Levinson 2001); low income elasticities for environmental quality (Kristrom and Riera 1996, McConnell 1997); or governments have other priorities (López and Mitra 2000)), it is possible that trends in environmental damage may only stabilise or continue to rise with income levels (Dagsupta et al 2002, Stern 2004). In other words, the pressures on, interactions between and rigidities associated with the demand for and supply of environmental quality are still poorly understood and deserve more research (Carson 2010). 
Having looked at trends in pollution, it is now necessary to look at the cost of each unit of pollution. To date, there has been little theoretical discussion. The only clue is related to the assumption about the damage function (Baumol and Oates 1988). If each unit of additional pollution causes more damage, then if pollution rises, then marginal and average external costs will tend to increase also. An explanation for this is that, at low levels of pollution, nature can assimilate pollution easily, but, as levels rise, natural waste assimilation services struggle to keep up and impose increasing damage for each unit. This might be especially relevant when flows of pollution create a stock or concentration of the pollutant, which determines the level of damage. It could be expected to occur both at the level of the environment (land, water, air or atmosphere) and individual bodies, where a person's health system becomes increasingly unable to deal with greater quantities of toxins, and suffers more from each additional quantity.

Yet, whether the marginal external costs are declining, constant or rising is, for now, an empirical question. If they increase at a constant rate, then examining external costs tells us little new. However, if they increase more than proportionally, studies focussing on pollution (such as the EKC literature) rather pollution costs underestimate the burden imposed on the wider society, as markets expand. Also, given that marginal external costs are likely to reflect the public's willingness to pay to reduce emissions, it also helps us to identify the demand for improvements in environmental quality. Thus, this process begins to provide a more structural analysis of the relationship between environmental pollution and economic growth.

\section{The Expansion of the British Coal Industry and Consumption}

Having looked at how external costs might be expected to vary through time, this paper will investigate this trend empirically by using the case of the coal expansion in Britain in the nineteenth century. It will try to identify how total and marginal (or average) external costs have varied through time in past energy markets.

Before examining external costs, though, it is worth briefly remembering the changes that took place to coal markets in the nineteenth century and early twentieth century. The coal mining industry expanded spectacularly, across regions in Britain and by exploiting deeper seams (Jevons 1865, Hatcher 1993, Flinn 1984, Church 1987). The latter was in large part due to the use of the steam engine for pumping-up water. The industry also benefitted from a rapidly growing labour force. In addition, by the 1830s, railways were able to distribute coal across the nation more effectively. Although cities like London continued to be supplied by waterway, average prices nearly halved between 1820 and 1850 (see Figure 1). Afterwards, prices stayed relatively constant, with some volatility. A growing population and industrial base pushed forwards demand. Growing demand and declining prices led to a rapid increase in coal consumption - rising from 20 million tonnes in 1820 to 
160 million tonnes in 1900. After 1913, coal consumption slumped, because of economic activity, restructuring and shifts to other energy sources. The decline of British coal, as an industry and as a source of energy, is a complicated mix of market restructuring, international competition, more valuable substitutes and environmental legislation (for details, see Ashworth 1986).

Figure 1. Coal Production or Consumption and Coal Prices in the United Kingdom (1800-2000)

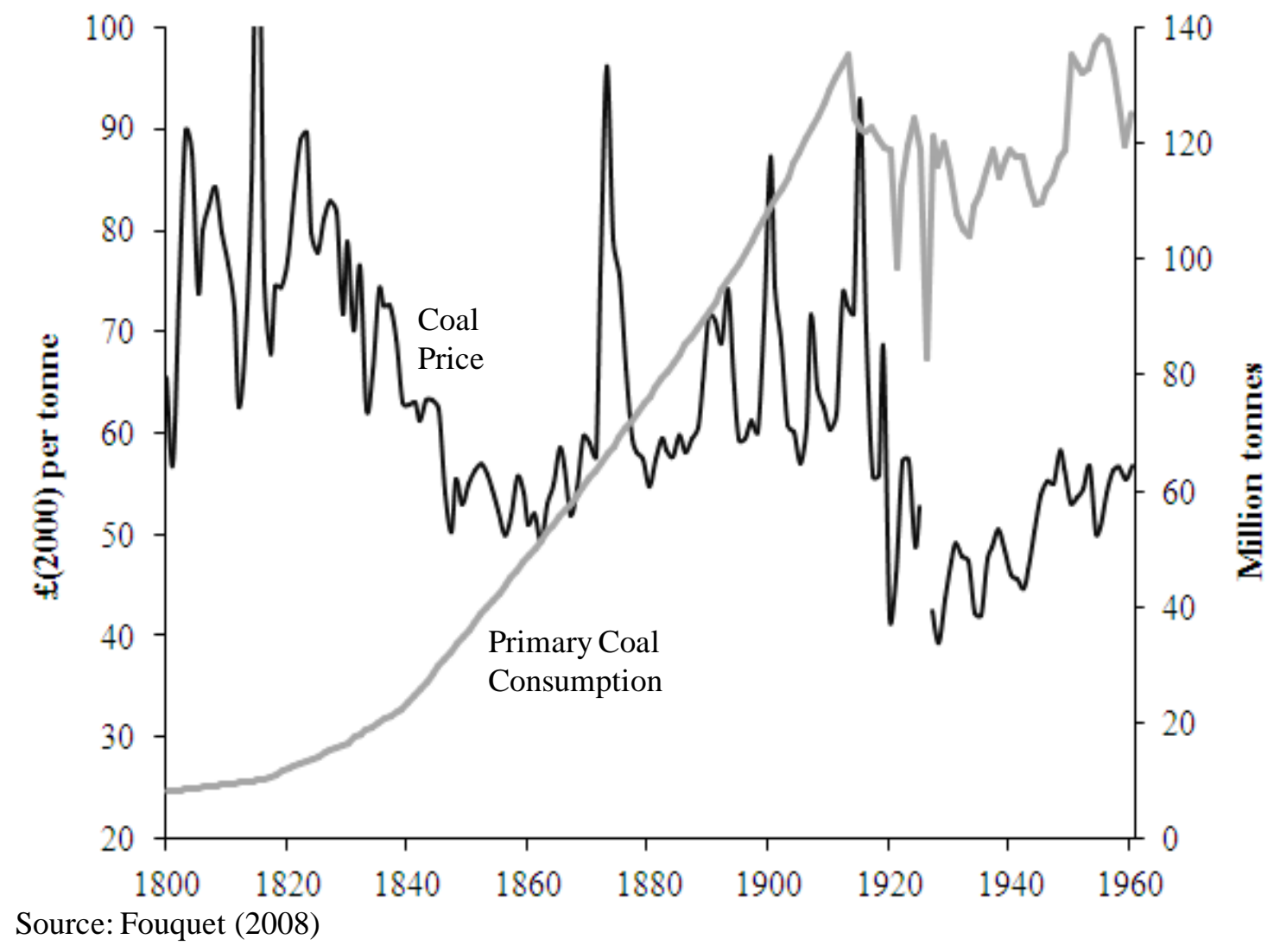

While the increase in the nineteenth century was pivotal to Britain's economic supremacy at the time, it also imposed high costs on its wider society. This paper will focus on deaths associated with coal production and consumption in the United Kingdom between 1700 and 2000, with an emphasis on the period from 1850 to 1920 . To achieve the objectives of the paper, the methodology used is relatively simplistic and does not take account of many of the external costs of coal ${ }^{3}$. Thus, this paper provides only a broad indicator of the trend in associated external costs.

\section{Mortality associated with Coal Mining}

The two main sources of mortality associated with coal mining were accidents and lung diseases, particularly pneumoconiosis (McIvor and Johnston 2007). For hundreds of years, collapsing

\footnotetext{
${ }^{3}$ ExternE (1995) presents the full external costs of coal for a United Kingdom power station in the early 1990 s.
} 
coal seams and fires underground have cast a dark shadow over mining communities across Britain. Annual deaths increased rapidly in the 1830s and 1840s following the industry's growth (see Figure 2). They peaked at the beginning of the twentieth century; 1,753 miners perished in 1913, at a time when more than one million employed in coal production - roughly, 1 in 600 died that year. As employment declined, productivity increased and safety standards improved (Supple 1987), deaths caused by accidents declined rapidly.

Pneumoconiosis was mainly connected with the dust resulting from the mechanisation of coal extraction and appears to have reached its peak in the 1960s (McIvor and Johnston 2007). Interestingly, these two sources of death are connected since mechanised drilling improved productivity, reducing the total number of workers and, so, accidental deaths, but also led to more respiratory problems. By the 1950s, pneumoconiosis deaths outnumbered accidental deaths by four to one.

One question that arises in this study is whether miners' deaths are costs that have been externalised. It could be argued that these greater risks are compensated for and internalised through higher wages. Given the rigidity of labour markets in coal mining towns and the social implications of losing family and community members, here, it is assumed that these deaths are external costs.

\section{The Rise in Mortality associated with Air Pollution}

The second external cost measured here are the deaths from local air pollution. Despite (no doubt) some lower rental prices to reflect neighbourhoods with higher air pollution concentrations, the lack of knowledge (both from residents and even the medical profession at the time) of the chronic impacts of air pollution (Brimblecombe 1987) suggest that the market was unlikely to properly internalise the costs of air pollution. So, these are also considered external costs.

During the nineteenth century, London and other British cities experienced increasingly severe and frequent fogs, which caused trains to stop running, court cases to be abandoned and crime rates to soar. The fog was coal smoke, trapped on windless days in the winter, when homes needed extensive heating, and the fog shielded the warmth from the sun. In the late nineteenth century, London averaged 80 days of dense fog per year! In parts of the city, such as West Norwood, in 1885, more than 180 days were recorded as foggy (Clay and Troesken 2010 p.62). The economic costs to London, and other major cities, grinding to a halt due to the fog were very large, although difficult to quantify.

A more measurable cost was the health damage. Respiratory diseases, especially associated with bronchitis, increased dramatically during and after foggy days. The average number of foggy days in London quadrupled from around 20 days in the 1820s and 1830s to 80 days in the 1880 s and 1890s (Clay and Troesken 2010 p.71). 
Pollution concentration in London grew rapidly during that period. According to Brimblecombe's (1987) model and the coefficient for converting smoke to TSP (Total Suspended Particulates) presented in Maddison and Gaarder (2002 p.5), the concentration of TSP appears to have risen from just under $400 \mu \mathrm{g} / \mathrm{m} 3$ (micro-grammes per cubic metre) around 1800 to $600 \mu \mathrm{g} / \mathrm{m} 3$ in 1890 (see Figure 3). For comparison, TSP concentrations in Delhi in the 1990s, one of the most polluted cities in the world, were around 370 $\mu \mathrm{g} / \mathrm{m} 3$ (Maddison and Gaarder 2002 p.10).

Figure 3. Mortality Rate attributed to Bronchitis in London and England \& Wales and Total Suspended Particulate (TSP) Concentration in London (1800-2000)

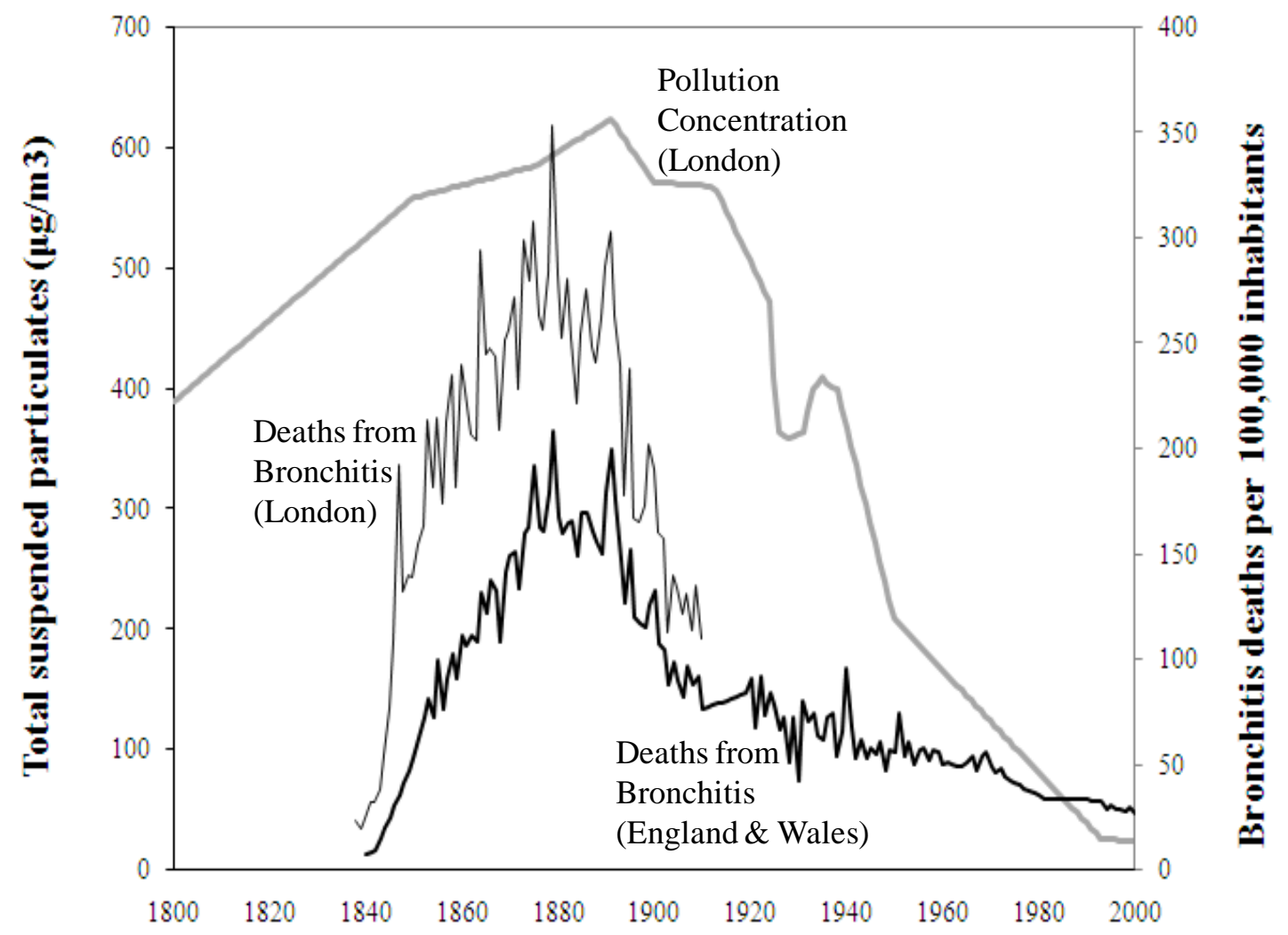

Source: Air Pollution: Brimblecombe (1987); Deaths: Registrar General (1838 onwards)

London mortality rates associated with bronchitis also rose, from 25 deaths per 100,000 inhabitants per year in 1840 to nearly 300 deaths in 1890 - 1 person in 350 died that year from bronchitis. As Figure 3 indicates, death rates rose much faster than concentration from 1840 to 1880 in London. This indicates that higher concentrations generate proportionally more deaths. This is equivalent to a rising marginal external cost, as consumption increases, or marginal benefits of abatement, as pollution increases.

One possible explanation for changes in death rates was a result of morticians' certification: that is, from the 1840 s, they began to increasingly diagnose deaths as due to bronchitis. Comparing 
the estimated air pollution concentration and mortality rates before 1850 and after 1920, more bronchitis deaths should be expected before 1850. Nevertheless, it is unlikely that certification explains the dramatic increase in bronchitis deaths during the nineteenth century (Crofton 1965).

Smoking may also explain some of the variation (Simpson 1962), particularly related to cigarette-smoking rather than other tobacco consumption (Christensen 1958). However, a rapid increase in British tobacco consumption and cigarette-smoking occurred around 1890, with the improved mechanisation of cigarette production. Cigarette sales increased from 6.5 million in 1884 to 313 million in 1893 (Hilton 2000 p.84) In other words, cigarette smoking fails to explain the increase in bronchitis during most of the nineteenth century and, in fact, coincides with the decline in bronchitis mortality rates from the 1890s. Instead, urbanisation and pollution have generally been connected with the variations (Simpson 1962, Crofton 1965).

Identifying which deaths are specifically due to air pollution is a difficult task. Given the data available, two avenues were possible to estimate deaths resulting from air pollution: identify the number of deaths caused by energy-related air pollution from those bronchitis deaths (which was used for the period 1850-1920) or use an exposure-response function (used for the periods before 1850 and after 1920). In the nineteenth century, air pollution seems to have been the main cause of bronchitis deaths, and the mortality statistics can be used to identify the damage caused by air pollution (Clay and Troesken 2010). Because of the apparent lack of other clear factors influencing nineteenth century bronchitis mortality and the rough estimate sought here, a simple approach was used for the period 1850-1920. It was assumed that, in the absence of air pollution, and other factors, such as smoking, the mortality rate would be 10 deaths per 100,000 people - this rate was deducted from the actual rate. This value was chosen because, in 2000, the rate was 25 per 100,000 inhabitants with less (but some) pollution, and more cigarette smokers.

By combining exposure-response functions (before 1850 and after 1920) and basic methods for attributing deaths due to air pollution (1850-1920) estimates suggest that the number of London bronchitis deaths due to air pollution increased from about 150 in 1700 , to 500 in 1800 , to 3,300 in 1850. It also indicates that, in London and the rest of the country, deaths peaked in 1891, when nearly 9,000 people died from bronchitis in the capital, and almost 72,000 perished in England and Wales.

Because of the relatively low assumed base rate (of 10 deaths per 100,000 living), these numbers are similar to the total actual bronchitis deaths. Naturally, they may overstate bronchitis deaths due to air pollution, but the estimates ignore other respiratory deaths initiated by smoke and particulate matter. Thus, this study may underestimate deaths resulting from coal combustion. 


\section{The Decline in Air Pollution Concentration and Mortality}

In the 1890 s, the air pollution problem in London (and in other cities) was partially resolved, even though emissions did not decline. While still high by twenty-first century standards, air pollution concentration halved over the next fifty years, dropping below $300 \mu \mathrm{g} / \mathrm{m} 3$ (see Figure 3).

Clay and Troesken (2010 p.52) offer three explanations for the decline in fogs and pollution concentration. First, at the end of the nineteenth century, with the advent of commuter railways, population began to spread into more suburban and, so, to live less densely. During the second-half of the nineteenth century, there had been a desire for upper-middle class families to live away from the crime, sewage and smoke (Luckin 2000). The introduction of the Cheap Trains Act of 1883 and a rapid expansion of suburban housing in the 1890s allowed a larger proportion of the population to live in suburbs and commute into the city, leaving the poorest in the centres (Thompson 1982, Jackson 2003, Burnett 1986). Thus, emissions were spread over a broader area. Although hard to pinpoint the exact timing of this spread quantitatively, the urbanised area of London increased five-fold between 1841 and 1901, halving the population density, which then declined three-fold between 1901 and 1951 (Demographia 2011). In addition to radically changing urban life, this suburbanisation of London and other cities in Britain was effectively a way of exporting the pollution.

Second, with the introduction of the Public Health Act of 1891, businesses in London that produced excessive smoke could be fined. This would have put some pressure on businesses to ensure that their fires were properly stoked (although there was always an economic incentive to do so, as it improved the efficiency of combustion) and to use the less polluting (but twenty percent more expensive) Welsh (steam and anthracite) coal (Clay and Troesken 2010 p.48).

A third explanation was that there was a possible shift towards gas for cooking and heating. Driven by the gas companies' initiatives to find new markets following competition from electricity in the lighting market, there was a rapid uptake of gas cookers during the 1890s and 1900s in London. The Gas Light \& Coke Company, which supplied two-thirds of London customers, noted that in 1892 only $2 \%$ of its customers had gas cookers and, by 1911, 69\% had them (Goodall 1999 p.105). While gas cookers were competitive and cleaner, gas heating was still three times more expensive than coal (Fouquet 2008 p.85). Much of the coal household demand, especially on cold days when the heavy fogs occurred, was not for cooking but for heating. Indeed, total coal consumption (excluding the coal used for gas works) in London still increased by 12\% from 1890 to 1910 (see, for instance, Clay and Troesken 2010 p.71) - implying that total emissions rose, as well. Given that much of the smoke problem in cities was associated with household consumption of coal for heating, the decline in population density (and the export of emissions) was probably the main explanation for the dramatic decline in air pollution concentrations. 
Mortality rates dropped even faster than concentrations - halving in twenty years (see Figure 3). By 1910, the number of air pollution-related bronchitis deaths dropped below 5,000 people in London and 30,000 in England and Wales.

From 1920, air pollution concentrations fell further as a result of a gradual shift towards more efficient heating equipment, and better quality and less polluting fuels, such as anthracite coal, coke, town gas and electricity (Fouquet 2008). There were still events like the Big Smog of 1952, which was associated with many lost lives and spurred a new generation of environmental legislation (Brimblecombe 1987). However, by the mid-twentieth century, pea-soup fogs were sporadic and shocking events rather than part of everyday life. After 1960, and the enforcement of the Clean Air Act of 1956, which designated most urban areas as smokeless (Thorsheim 2006 p.113), pollution and respiratory diseases due to coal combustion declined further. For the second-half of the twentieth century, electricity generation was the main coal user and only a minor source of mortality.

Taking account of the lower national mortality rate, but similar growth rates in pollution concentration across the country, these estimates were extrapolated for all of England and Wales: it rose from 2,400 in 1800 , to more than 20,000 in 1850 , to over 50,000 in 1900 and down to around 12,000 in 1950 (see Table 1 for detail). Over these 300 years, an estimated 4.5 million people died as a result of coal production and consumption!

Table 1. Estimates of Annual Deaths due to Coal Production and Consumption in the United Kingdom (1700-2000)

\begin{tabular}{lcccc}
\hline & $\begin{array}{c}\text { Coal Mining } \\
\text { Accidents }\end{array}$ & $\begin{array}{c}\text { Coal Miner's } \\
\text { Pneumoconiosis }\end{array}$ & Air Pollution & Total \\
\hline 1700 & 2 & $\mathrm{Na}$ & 450 & 452 \\
1750 & 4 & $\mathrm{Na}$ & 980 & 984 \\
1800 & 38 & $\mathrm{Na}$ & 2,400 & 2,438 \\
1850 & 630 & $\mathrm{Na}$ & 20,250 & 20,880 \\
1900 & 1,450 & 200 & 50,450 & 51,900 \\
1950 & 500 & 800 & 12,125 & 13,425 \\
2000 & 0 & 0 & 136 & 136 \\
\hline
\end{tabular}

Source: see text. Note: to restate, these are broad (not accurate) estimates. 


\section{Long Run Trends in the Value of a Statistical Life and a Life Year Lost}

Having estimated the number of deaths, the next step is to place a value on them. This process is inevitably controversial (Cameron 2010). A common approach to placing an economic value on mortality is to use the value of an individual 'statistical' life (VOSL). For the United Kingdom, a number of studies offer ranges of estimates for the value of a statistical life. They range from a low-value estimate of $£ 0.5$ million for 1982 to a high-range estimate of $£ 15.2$ million in 1996 (see Table 2). Given that here the objective is to use a single value per year, an average of the averages was taken. The average value for each statistical life lost in the United Kingdom for 2000 was calculated to be $£ 5.1$ million. This is similar to Viscusi and Aldy's (2003) range of \$5.5-\$7.5 million for the US. The reader who would like to use a different value can adjust estimates, as the estimates are scalable (Murphy and Topel 2006).

Table 2. A Selection of Values of a Statistical Life (£million) in the United Kingdom

\begin{tabular}{lcccc}
\hline Study & Year & Average & Low & High \\
\hline Beattie et al. (1998) & 1996 & 8.3 & 1.3 & 15.2 \\
Pearce and Cowards (1995) & 1993 & 2.3 & & \\
Carthy et al (1999) & 1997 & 4.6 & 4.0 & 5.2 \\
Jones-Lee et al(1983) & 1982 & 5.4 & 0.5 & 10.2 \\
\hline Avaerage & & 5.1 & & \\
\hline
\end{tabular}

Source: see table

It has recently been shown that there is substantial heterogeneity in the value of a statistical life (Viscusi 2010). Age differences and occupational hazards (Aldy and Viscusi 2007), wage compensation (Kniesner et al 2010), existing risk level (Viscusi and Aldy 2003) and culpability (Covey et al 2010) can influence the value.

In the current study, though, these are premature deaths rather than fatalities that would be otherwise completely avoided. Amongst victims, there is considerable variation in the number of years lost due to premature death. For some, say elderly people whose deaths were accelerated due to respiratory problems aggravated by air pollution, only a few years may have been lost. On the other end, a young coal miner crushed under a fallen seam may have lived many decades further. Thus, a value of a life year lost (VOLY) approach is also being used (DEFRA 2007). This approach identifies the number of years prematurely lost and multiplies this number by the value of a life year lost (Murphy and Topel 2006, Aldy and Viscusi 2007). The VOLY used for United Kingdom air pollution studies is $£ 29,000$ per year lost (DEFRA 2007). 
This offers an indication of the value at the end of the twentieth century. However, this study is also interested in lives lost decades and centuries before. Following Murphy and Topel (2006 p.891), a benefit transfer (Krupnick et al 1996, Smith et al 2006, Alberini et al 2008) on past years in the same country is used to estimate the value of past life years lost. The main variable influencing the value of past lives will be the current value of a life year lost and per capita income, using data from the Office for National Statistics (2010), Mitchell (1988) and Broadberry et al (2010).

There are very few longitudinal studies of VOSL. The only one over a long period of time (Costa and Kahn 2004) offers an interesting example for the US between 1940 and 1980, and indicates that the value of a statistical life rose at a faster rate than income during this period. Hammitt and Robinson (2011), although proposing that VOSL is a luxury good, show that the range of income elasticity estimates varies from 0.2 to 1.6. To take account of the views that willingness to pay for air pollution improvements probably does not vary proportionally with income (Krupnick et al 1996, Viscusi and Aldy 2003, Viscusi 2008) an income elasticity of 0.8 was used for the main values.

Figure 4. Estimates of the Value of a Life Year Lost in England and Wales (1700-2000)

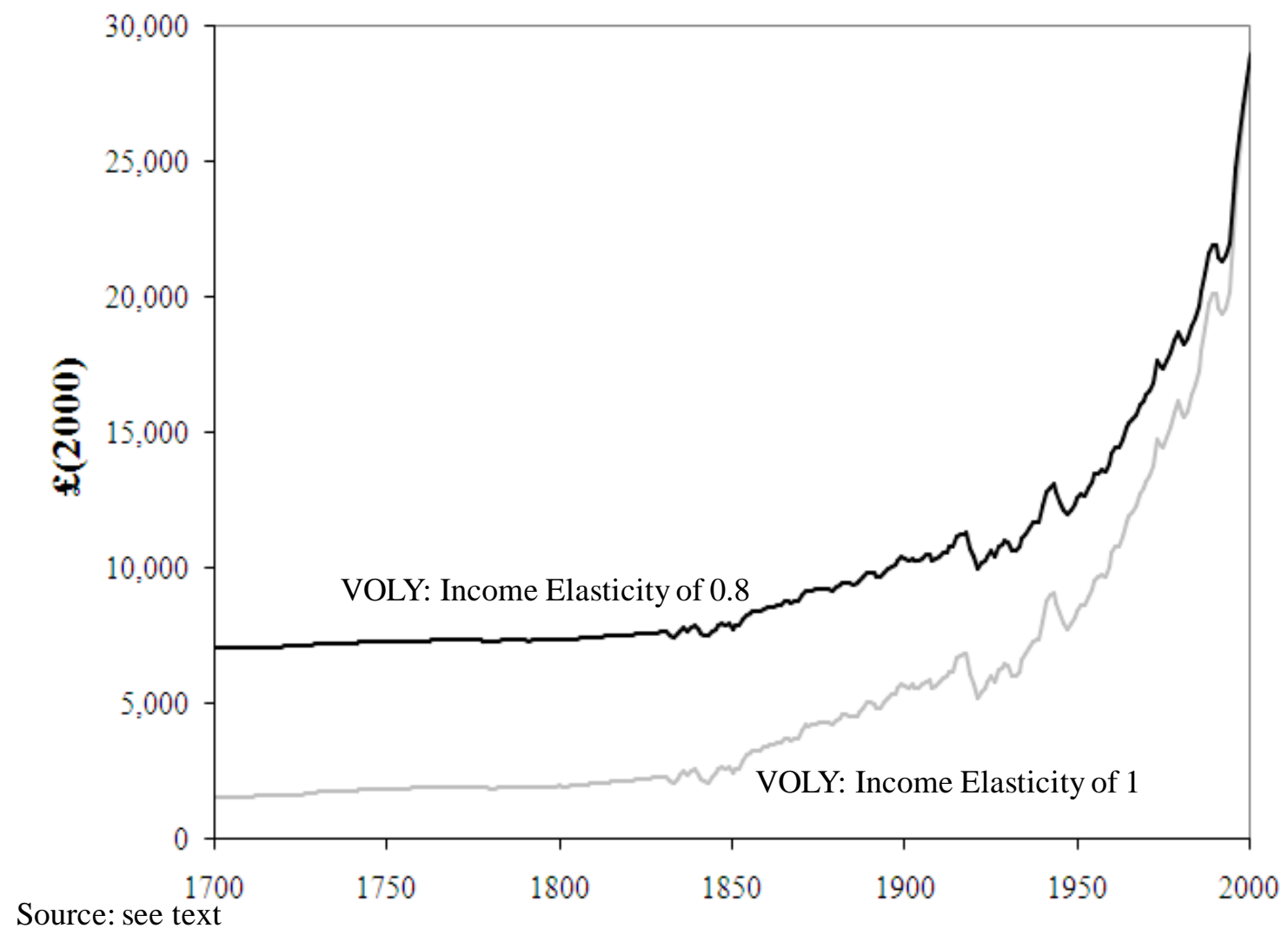

From this, a series for the value of a life year lost was estimated back to the eighteenth century. Per capita income was roughly $90 \%$ lower in 1800 and $80 \%$ lower than in 2000; so, the value 
of life year lost (in 2000 money) was calculated to be close to $£ 8,120$ (i.e., $72 \%$ lower: $90 \%$ multiplied by 0.8 for the income elasticity) in 1800 and $£ 10,4400$ (i.e., $64 \%$ lower: $80 \%$ multiplied by 0.8 for the income elasticity) in 1900 (see Figure 4). To provide a comparison, the values assuming a unit income elasticity of demand (for avoiding mortality risks from air pollution) are also presented.

Now, it is necessary to estimate the number of life years lost. Cropper et al (1997) highlight the different age distributions of air pollution-related deaths in developed and developing countries. In England and Wales, the ages at which people died from bronchitis changed substantially from 1850 to 2000 (see Table 3). In 1850 and 1890, around $40 \%$ of the deaths were from under five year olds. This fell to $23 \%$ in 1910 and $0.1 \%$ in 2000 . The share of over 65 year olds increased rapidly between 1890 and 1910, and continued to increase through the twentieth century.

Table 3. Age Distribution of Deaths from Bronchitis in England and Wales (1850-2000)

\begin{tabular}{llllc}
\hline & Under 5 & $5-19$ & $20-64$ & 65 and over \\
\hline 1850 & $39.2 \%$ & $2.5 \%$ & $36.1 \%$ & $22.3 \%$ \\
1890 & $42.9 \%$ & $1.2 \%$ & $29.1 \%$ & $26.8 \%$ \\
1910 & $23.7 \%$ & $0.8 \%$ & $14.1 \%$ & $61.4 \%$ \\
2000 & $0.1 \%$ & $0.0 \%$ & $13.7 \%$ & $86.2 \%$ \\
\hline
\end{tabular}

Source: Registrar General (1851 onwards)

However, life expectancy was much shorter in the eighteenth or nineteenth century than in the late twentieth century. The life expectancy at birth (i.e. age zero) has been estimated from the midsixteenth century in England (Wrigley and Schofield 1981). Average life expectancy (at birth) was found to be about 38 years old in 1700, dropping slightly in 1750, and rising again in 1800 to about 40. It rose from 42 in 1850 to 49 in 1900, leaping to 60 in 1925 and 70 by 1950, and reaching about 77 years old in 2000 (Cervellati and Sunde 2005).

By combining the age distribution of deaths from bronchitis with a model of life expectancy, it was possible to estimate the average number of years lost per death resulting from bronchitis. The changes in the two variables somewhat cancelled each other out, such that, life years lost remained relatively constant over three centuries: it increased from 18 years in 1700 to 19 in 1800 , to 20 in 1900 , and down to 15 in 2000.

These estimates can then be multiplied with the value of a life year lost to estimate the value of the average life lost in a particular year: in 1800, the value of an average life lost (from bronchitis) is estimated (in 2000 money) to be $£ 37,000$ in $1800, £ 116,000$ in 1900 and $£ 428,000$ in 2000 - far below the $£ 5.1$ million of a statistical life. 


\section{Estimates of the Long Run Trends in the External Costs of Coal}

The next step was to estimate the value of the lives lost and convert them into a value per tonne of coal. Just like future events, it could be suggested that past events should be backward discounted to reflect current allocation preferences between the present and the past (Wolf 1970, Ray and Wang 2001, Caplin and Leahy 2004). However, here, estimations of external costs are not used to determine the present value of past events but to identify the cost to society (as well as the share of price to marginal social costs) at different moments in time.

Figure 5 shows the trend in total external costs. Naturally, the trend during the nineteenth century follows the mortality rates associated with air pollution (see Figure 3), rising rapidly until the 1880s. It peaked in 1891, when air pollution from coal was estimated to have caused close to $\mathfrak{f}(2000) 17.5$ billion in damage (black line in Figure 5). Close to 73,000 people were estimated to have died as a result of coal production and consumption. During the twentieth century, the trend also reflects the rapid decline in air pollution concentrations from the 1890s and in the mid-twentieth century. The famous Big Smog of 1952 was indeed a relatively mild affair compared with what had come before.

Naturally, a critical factor is the value used. For a basic sensitivity analysis, the estimates generated using a VOLY with an income elasticity of 1 provides a low range value and a VOSL (also with an income elasticity of 1) presents a high-end estimate. They also peak in 1891, offering a range from $£(2000) 10$ billion to $£(2000) 65$ billion. To spread the range further and higher, the value of a statistical life could have been presented using an income elasticity of 0.8 or lower, and damages would been estimated to be more than $£(2000) 100$ billion (following Krupnick et al (1996)). Now, for such long periods, a low income elasticity does produce questionable values of a life year lost (or a life). On the other hand, there are still doubts about the suitability of using the value of a life year lost, since the value of a statistical life probably does not change linearly with age (Alberini et al 2008). Also, this methodology has been recommended in a context (i.e. the twenty-first century) when the majority of the deaths were for aged people, with potentially few years left to live (DEFRA 2007). However, in the nineteenth century, more than $40 \%$ of deaths were under fives, potentially robbing them of their whole lives, even if they were relatively nasty, brutish and short. Taking these points into account, the central value does seem like an appropriate compromise, and does provide an indicator of the rise in total and average external costs.

To provide some additional perspective, Figure 5 also presents consumer expenditure on coal. This acts as an indicator of the welfare value associated with coal consumption. The appropriate indicator is the marginal consumer surplus (not price) multiplied by consumption, but this is not possible to estimate here. Between 1870 and 1895, consumer expenditure was about two-thirds of the total external costs. In other words, during this period, the total consumer surplus would have had to 
have been fifty percent higher than consumer expenditure to have matched the total external costs, and to have provided society with positive utility from this level of consumption. Effectively, coal consumption was probably far higher than was socially desirable.

Figure 5. Range of Estimates of Total External Costs Associated with Coal Production and Consumption (in Comparison with Coal Expenditure) in England and Wales (1700-2000)

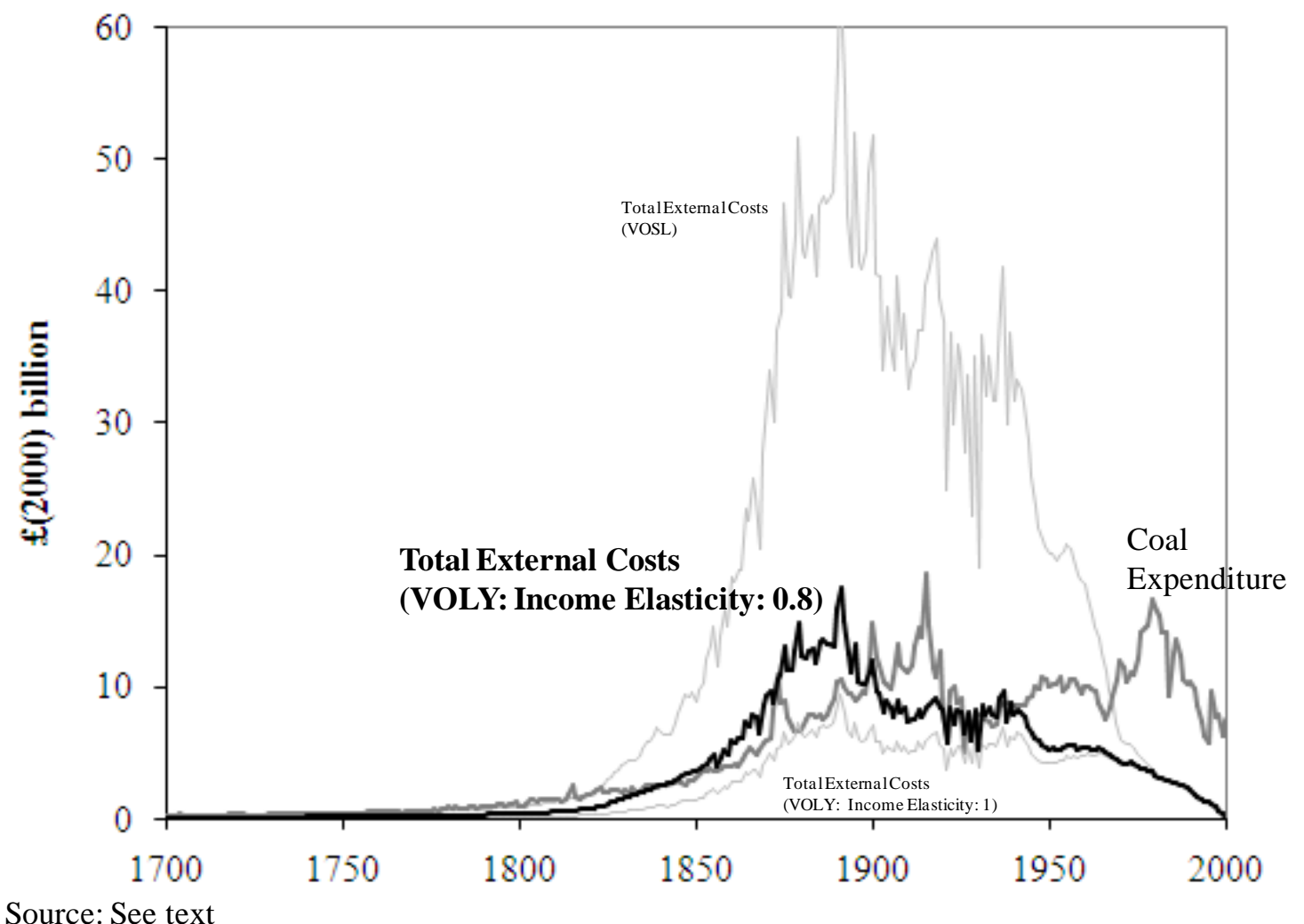

Source: See text

Also, as an indicator of the scale of damage, total external cost can be compared with GDP. In 1820 , the total damage was estimated to be equivalent to $4 \%$ of GDP. This reached $9 \%$ in 1850 . It ranged from $15 \%$ to $20 \%$ of GDP between 1870 and 1890, peaking in 1879. In 1891, the damages were estimated to be $17.3 \%$, at a time when the GDP was $£(2000) 100$ billion . By 1950, the damage had fallen to $2 \%$ of GDP.

The final step was to convert total external costs into unit costs. For theoretical purposes marginal costs are sought; however, they are impossible to estimate in this case. Instead, average external costs (i.e. total external costs divided by total primary coal consumption) can be calculated. They provide a clear indication of the marginal values: when average external costs rise, marginal costs have risen further; when averages fall, marginal values have fallen further. 
Figure 6 presents the trend in the price of coal and average external costs, along with the percentage in the average social costs (i.e., the sum of the marginal private costs (here, proxied by the price) and marginal external costs). The first observation is that in the eighteenth century average external costs were already significant. The introduction and adoption of chimneys across Britain allowed dwellings to use coal and eject the smoke, thus, not suffer their unpleasant consequences (Fouquet 2008). At that time, external costs were estimated to be responsible for around 20-25\% of the social costs of energy production and consumption.

Figure 6. The Price of Coal, Average External Cost, and the Percentage of the Average External Costs (AEC) in the Average Social Costs (ASC)* in England and Wales (1700-2000)

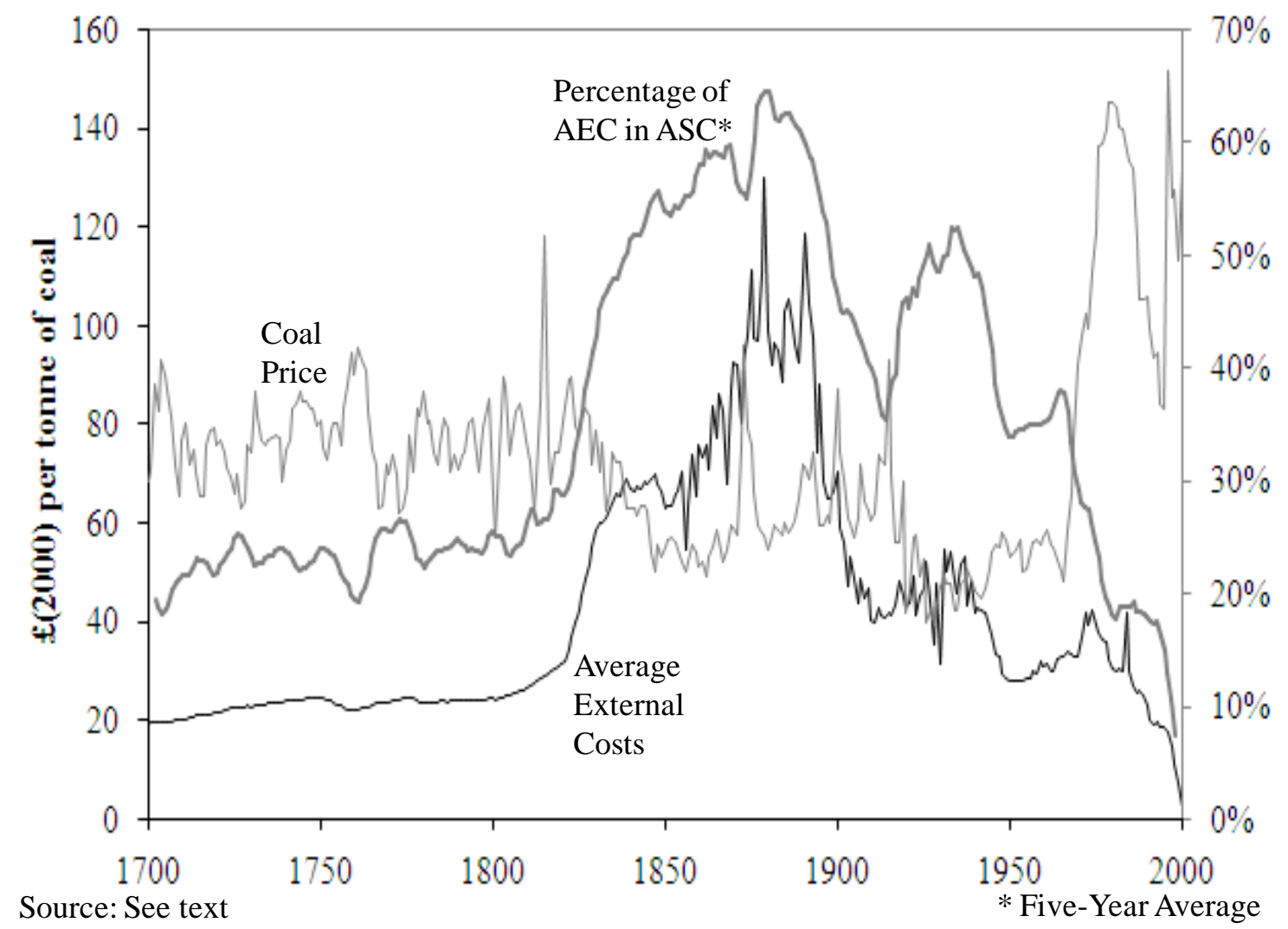

The second point is that when prices fell between 1820 and 1850, along with a rise in demand associated with a growing population and economy, consumption soared (see Figure 1), and so did average and marginal external costs . From the mid-1870s to the early-1890s, these external costs were estimated to be $60-70 \%$ of the social costs (see Figure 6). Thus, consumers were benefitting from cheap coal, but society as a whole was paying twice as much (for each tonne of coal consumed). 


\section{Market and Government Failures}

The estimates indicate that the marginal social costs far outweighed the marginal social benefits of consuming coal. In 1850, the marginal (i.e. the final or 60 millionth) tonne consumed was valued at the price (i.e. $£(2000) 55$ ). But, the average external cost at the time was $£(2000) 62$. Given that the evidence suggests that the external costs rose more than proportionally with pollution, the marginal external costs must have been far greater. So, society in 1850 was suffering far more than $£(2000) 62$ for a tonne of coal that was only valued at $£(2000) 55$. And, this marginal cost-benefit analysis worsened after 1850. No doubt, many millions of tonnes of coal were consumed that imposed far more damage than benefit. To work out the optimal level of coal consumption would require knowledge of the consumer surplus (the demand curve or the marginal private benefits of consumption) and the marginal external cost curve (not just the average costs). But, given that prices (and marginal benefits of consumption) remained relatively stable afterwards, by 1850 , it was socially sub-optimal for marginal and average external costs to be rising further. The nineteenth century British coal consumption was a clear example of market failure.

Had households been taxed to pay the full social costs, it is questionable how much coal would have been consumed in nineteenth century Britain. Households may have been colder, or they may have insulated their homes more effectively, used more efficient stoves rather than fireplaces and used less polluting fuels. But, in the early 1800 s, when average external costs were beginning to escalate, or throughout the nineteenth century, when pollution abatement societies were being formed to put pressure on the authorities, blinding fogs and respiratory diseases had often been accepted as the price to pay for wealth and warmth (Brimblecombe 1987, Mosley 2001).

Yet, factors were in place by the 1850s to resolve the problem: businesses knew that good stoking was the key to both using coal efficiently and reducing smoke emissions (Thorsheim 2006 p.18); Continental and Scandinavian homes had used far more efficient stoves for heating at least since the eighteenth century (Fouquet 2008 p.79); gas cookers began being used in the 1840s, and there was extensive gas supplies in all towns across the country (Goodall 1999 pp.24-9); there were other smokeless fuels, such as anthracite coal (available in the South West of Wales) and coke (produced by carbonising the coal first), that could have been used by households for heating purposes (Jevons 1865 p.156); and, railroads could have expanded the limits of the city, spreading the air pollution and reducing concentration (Jackson 2003). So, opportunities for mitigation existed.

Naturally, mitigation would have imposed substantial costs. The factors that enabled air pollution concentrations to decline at the end of the nineteenth century had benefitted from several additional decades of development (particularly, in the railway, gas and coke industries) to achieve economies of scale and lower prices (Fouquet 2011). Therefore, mitigation in the 1850s, say, rather 
than the 1890s would have been substantially more expensive. Although very difficult to estimate (and requiring an extensive counterfactual study), it is questionable whether these costs would have amounted to $15-20 \%$ of GDP, as the external costs did.

The barriers to addressing the problem appear to have been a perception of the risk and government failures. Possibly encouraged by industrialists fearing environmental legislation, there were many dissenters that questioned the harmfulness of air pollution. It was only in the 1880s that the widespread belief that smoke actually cleansed the air of impurities (known as the miasma theory) was rejected, and a consensus formed about the health damage caused by smoke (Thorsheim 2006 p.195).

Despite dissenters and uncertainties about the dangers of smoke, from the 1860s, pressure groups, such as the Smoke Abatement Societies, tried to influence environmental legislation. Numerous scientists tried unsuccessfully to incorporate coal smoke into the Alkali Act of 1863. The Sanitary Act of 1866 finally required (rather than allowed) municipal officials to prosecute owners of smoky businesses. However, loopholes (related to wording of the act) and exemptions implied it was not enforced. Similarly, the Public Health Act of 1875 (which did not apply to London) stated that smoke nuisances should be reduced "as far as practicable", and leniency was common. The Public Health (London) Act of 1891 introduced equally weak and lenient legislation to the capital, only addressing certain businesses and not households, which were the main culprits (Thorsheim 2006 pp.113-5).

Perhaps because pollution concentrations began to improve, and marginal and average external costs did fall (fifty years later than was probably optimal), environmental legislation remained toothless. Nevertheless, until the middle of the twentieth century, average external costs remained close to the price (i.e. the marginal benefits of consumption). In 1956, when British primary coal consumption actually peaked, an estimated one-third of the social cost was still being externalised. Average external costs fell dramatically with the enforcement of the Clean Air Act of 1956. This legislation, in addition to formally stating emission levels for firms, finally addressed the burden that household coal consumption had been imposing on society for centuries, by specifying that urban areas were to be smokeless zones (Thorshiem 2006 p.113). Thus, stringent environmental legislation on smoke emissions was introduced more than one hundred years after it was probably optimal to have done so. As a result, while coal is still responsible for many other external costs, including those associated with climate change, its impact on local air pollution mortality has become negligible. 


\section{Conclusion}

\section{A Historical Trend in External Costs}

The purpose of this paper was to begin to investigate how external costs have changed through time. To do so, this paper investigated a major period in energy history, nineteenth century Britain, often associated with the fuelling of the Second Industrial Revolution (Church 1986, Allen 2009). During the nineteenth century, the rapid growth in urban population and income levels, coupled with a decline in coal prices, led to soaring coal consumption and deadly fogs in the cities.

To place an economic cost on those deaths, simple valuation techniques based on the value of a life year lost (and the value of a statistical life for comparison) were used. The central value estimated that, at its peak, in 1891, this was equivalent to $£(2000) 17.5$ billion in damage, at a time when Britain's GDP was $\mathfrak{f}(2000) 100$ billion. The proportion of average social costs of coal that was externalised increased from around $20-30 \%$ before 1820 to two-thirds between 1870-1890, then falling to $40-50 \%$ in the first half of the twentieth century, and then declining rapidly after 1960.

The estimates of external costs are not meant to be accurate. The paper ignored many external costs (ExternE 1995), including land subsidence, contamination of water systems, disruptions to daily life and economic activity, rising crime rates, degradation of buildings, reduction of crop yields, ecosystem loss and degradation, and climate change. Also, the method for estimating the number of deaths (particularly related to air pollution) was crude. In addition, the approach to valuing the loss of life was basic. There is considerable debate about the income elasticity of the value of a life (Krupnick et al 1996, Costa and Kahn 2004, Hammit and Robinson 2011, Jones 2011). An alternative approach, but fraught with complexities (due to market failures in the labour market, unionisation, skills, safety legislation, insurance coverage changes and regional variations in wage rates (Hinterman et al 2010)), would have been to estimate the value of a life based on the wage differential for jobs with greater risk of mortality (Costa and Kahn 2004). Thus, this paper offers only an indication of trends in historical external costs.

\section{The Dynamics of the Demand for and Supply of Environmental Quality}

The trend in total and average external costs can be seen as a reflection of the shifts in the demand for and supply of air quality, and the rigidities in supply responding to demand. A decline in the supply of air quality (due to the growth in urban coal consumption) during the nineteenth century, coupled with a rising marginal damage function, increased the related external costs and the demand for air quality improvements. Supply failed to respond, because of the lack of incentives to reduce emissions.

By comparing the average external costs with the average benefits of consumption (using price as a proxy), it suggests that, certainly by 1850 , British coal consumption was socially sub- 
optimal (i.e., too high). Government needed to intervene and influence supply. However, in the second-half of the nineteenth century, despite the availability of solutions to reduce emissions and concentrations, demands to regulate were met with weak legislation (which failed to address the main culprits, households) and limited enforcement. Thus, government failed to provide genuine incentives.

In one sense, exogenous factors (particularly suburban development) were responsible for the air quality improvements at the end of the nineteenth century. In another, changes in the housing market reflected a delayed market reaction to many urban problems of the time, such as crime, sewage and smoke, which had not been properly addressed by markets directly related to these issues or government (Burnett 1986). Therefore, these failures left it to society, through the housing market, to adapt. It did, very slowly, and at a very high cost to society, with the poorest suffering the most.

As Carson proposed (2010), this paper concurs that, analysing the dynamics of, interactions between and rigidities in the demand for and supply of environmental quality can help to understand the relationship between economic growth and environmental quality. It also suggests that often environmental legislation does require extreme situations to intensify the pressure on government to introduce bills associated with the environment - and, therefore, act as a conduit between the demand and supply. However, government may not necessarily address the main causes, receive the support needed in parliament or enforce legislation once introduced (Kahn 2007). Consequently, the market and government often leaves the outcome of environmental problems to a mix of poorly understood partially exogenous and partially endogenous forces.

\section{Lessons for the Growth in Greenhouse Gas Emissions}

One should be very cautious about using a historical experience to draw conclusions about another environmental problem. This is especially true since, first, air pollution is a local problem and climate change is a global one, and, second, greenhouse gases are stock pollutants, where as air pollution is a problem of flow. Although it is only one case study, reflecting its particular physical, technological, economic, social, political and cultural characteristics, it can provide a cautionary tale.

In particular, greenhouse gas emissions and concentrations have increased rapidly over the last fifty years, a demand does exist for greenhouse gas mitigation, mitigation solutions do exist (even if some are costly), polluters have little incentive to reduce emissions, the damage function related to climate change is likely to rise with increasing concentrations, dissenters do question the science, and legislation has tended to be weak and enforced with difficulty. This suggests that, regarding climate stability, supply is shifting to the left, demand is shifting to the right, and, if a price (i.e., where demand and supply met) for climate stability existed, it would be rising sharply. However, demand and supply do not meet in an equilibrium, and governments need to be the conduit between demand and supply.

Based on the historical experience studied in this paper, it may require very high external costs and long delays before governments act as a conduit, especially since the main polluters are 
consumers, citizens and voters. It is probable that supply and demand will adjust and adapt, but only very slowly. In the meantime, most anticipate that the supply of climate stability will shift further to the left (as global populations and incomes rise) and demand may shift more to the right (especially if weather systems become exponentially more damaging with concentrations (Weitzman 2009)), imposing a high cost to society with, again, the poorest suffering most.

\section{Future Research}

Three lines of investigation follow from this paper. The first is a better theoretical understanding of the dynamics of the demand for and supply of environmental quality (including the market and government failures) influencing the relationship between economic growth and environmental quality. The second is to provide additional empirical evidence to indicate whether the case studied here was an extreme and exceptional case. It is important to understand whether such dramatic increases in average external costs have occurred in other contexts and whether it is likely to be imposed again.

Third, researchers need to explore the appropriate policies as external costs change in periods of rapid economic growth. Just like in nineteenth century Britain, identifying the desired balance between wealth and health is difficult and politically sensitive. Similarly, how governments should act to improve the situation is unclear. For instance, the principle of internalising the external costs of energy use has generally focused on correcting (e.g. taxing or creating trading permits) relatively small shares of the social costs (Nordhaus 2007). While market-based instruments are flexible in principle, major increases in carbon taxes or large reductions in the supply of tradable permits are politically unacceptable. Thus, economists may need to think about how to develop instruments that can genuinely adjust to dramatic increases in external costs.

But, what happens in extreme cases, when the external costs are several times the price? Weitzman (2009) highlights the risks of very high external costs associated with energy use. While many may discard these as low-risk events, an awareness that the burden from energy consumption on the wider society has been very high in the past and can get much worse may help concentrate minds a little more towards finding solutions, and not simply accepting that climate change is the price to pay for economic growth and development. 


\section{References}

Alberini, A., Tonin, S, Hunt, A. 2008 Literature Review about VSL over time: Estimating the mortality benefits of environmental policies. A Report for the EXIOPOL Project n. 037033.

Aldy, J.E., Viscusi, W.K. 2007. Age differences in the value of statistical life: revealed preference evidence. Review of Environmental Economics and Policy. 1(2), 241-260.

Allen, R.C. 2009. The British Industrial Revolution in Global Perspective. Cambridge University Press, Cambridge.

Andreoni, J., Levinson, A. 2001. The simple analytics of the environmental Kuznets curve. Journal of Public Economics 80(2) 269-286.

Ashworth, W. 1986. The History of the British Coal Industry. Vol 5. 1946-1982. The Nationalized Industry. Clarendon Press. Oxford.

Baumol, W.J., Oates, W.E. 1988. The Theory of Environmental Policy. $2^{\text {nd }}$ Edition. Prentice-Hall. Englewood Cliffs, NJ.

Beattie, J., Covey, J., Dolan, P., Hopkins, L., Jones-Lee, M.W., Loomes, G., Pidgeon, N., Robertson, A., Spencer, A., 1998. On the contingent valuation of safety and the safety of contingent valuation. 1. Caveat investigor. Journal of Risk and Uncertainty 17, 5-25.

Bickel P., Friedrich, R. 2005. Externalitites of Energy - Methodology 2005 Update. European Commission EUR 21951. http://www.externe.info.

Brimblecombe, P. 1987. The Big Smoke: A History of Air Pollution in London Since Medieval Times. Methuen. London.

Broadberry, S., B. Campbell, A. Klein, M. Overton, B. van Leeuwen (2010) British Economic Growth 1270-1870.

http://www2.warwick.ac.uk/fac/soc/economics/staff/academic/broadberry/wp/

Burnett, J. 1986. A Social History of Housing 1815-1985. Methuen. London.

Cameron, T.A. (2010) Euthanizing the Value of a Statistical Life. Review of Environmental Economics and Policy. 4(2), 161-78.

Caplin, A. Leahy, J. 2004. The Social Discount Rate. Journal of Political Economy. 112(6) 12571268.

Carson, R. 2010. The Environmental Kuznets Curve: seeking empirical regularity and theoretical structure. Review of Environmental Economics and Policy. 4(1), 3-23.

Carthy, T., Chilton, S., Covey, J., Hopkins, L., Jones-Lee, M.W., Loomes, G., Pidgeon, N., Robertson, A., Spencer, A., 1999. On the contingent valuation of safety and the safety of contingent valuation. 2. The CV/SG "chained" approach. Journal of Risk and Uncertainty 17, 187-213.

Cervellati, M., Sunde, U. 2005. Capital Formation, Life Expectancy, and the Process of Development. American Economic Review. 95, 5, 1653-1672. 
Christensen, O.W., Wood, C.H. 1958. Bronchitis Mortality Rates In England And Wales and in Denmark. British Medical Journal. 1(5071), 620-2.

Church, R. (1986) The History of the British Coal Industry. Vol 3. 1830-1913. Clarendon Press. Oxford.

Clay, K., Troesken, W. 2010. Did Frederick Brodie Discover the World's First Environmental Kuznets Curve? Coal Smoke and the Rise and Fall of the London Fog, NBER Working Papers 15669. National Bureau of Economic Research.

Cole, M.A. 2004. Trade, the pollution haven hypothesis and the environmental Kuznets curve: examining the linkages. Ecological Economics 48(1) 71-81.

Costa, D., Kahn, M.E. 2004. Changes in the value of life, 1940-1980, Journal of Risk and Uncertainty 29 (2) $159-180$.

Covey, J., Robinson, A., Jones-Lee, M., Loomes, G. 2010. Responsibility, scale and the valuation of rail safety. Journal of Risk and Uncertainty. 40(1).

Crofton, E. 1965. A comparison of the mortality from bronchitis in Scotland and in England and Wales. British Medical Journal 1: 1635-9.

Cropper, M., Simon, N., Alberini, A., Arora, S., Sharma, P.K. 1997. The Health Benefits of Air Pollution Control in Delhi, American Journal of Agricultural Economics. 79, 1625-1629.

Dasgupta, S., Laplante, B., Wang, H., Wheeler, D. 2002. Confronting the environmental Kuznets curve. The Journal of Economic Perspectives 16(1) 147-168.

DEFRA (2007) An Economic Analysis to inform the Air Quality Strategy: Updated Third Report of the Interdepartmental Group on Costs and Benefits.

Demographia. 2011. London Urbanized Area: Historical Estimated Population \& Density. http://www.demographia.com/db-lonuza1680.htm.

Dinda, S. 2004. Environmental Kuznets curve hypothesis: A survey. Ecological Economics. 49, 43155.

Dorfman, R. 1977. Incidence of the benefits and costs of environmental programs. American Economic Review 67 333-340.

ExternE (1995), Externalities of Energy, Vol. 3, Coal and Lignite, European Commission DGXII, SRC, Report nr. EUR16522EN, Brussels. http://www.externe.info.

Flinn M.W. 1984. The History of the British Coal Industry. Vol 2. 1700-1830. Clarendon Press. Oxford.

Fouquet, R. 2008. Heat Power and Light: Revolutions in Energy Services. Edward Elgar Publications. Cheltenham and Northampton, MA, USA.

Fouquet, R. 2010. The Slow Search for Solutions: Lessons from Historical Energy Transitions by Sector and Service. Energy Policy. 38(10) 6586-96. 
Fouquet, R. 2011. Divergences in long run trends in the prices of energy and energy services. Review of Environmental Economics and Policy 5(2).

Goodall, F. 1999. Burning to Serve: Selling Gas in Competitive Markets. Landmark Publishing. Ashbourne.

Grossman G.M., Krueger A.B. 1995, Economic growth and the environment. Quarterly Journal of Economics. 110, 353-77.

Hammitt, J.K., Robinson, L.A. 2011. The Income Elasticity of the Value per Statistical Life: Transferring Estimates Between High and Low Income Populations. Journal of Benefit-Cost Analysis 2(1) $1-27$.

Hilton, M. 2000. Smoking in British Popular Culture, 1800-2000: Perfect Pleasures. Manchester University Press. Manchester.

Hintermann, B., A. Alberini, and A. Markandya. 2010. Estimating the Value of Safety with Labour Market Data: Are the Results Trustworthy? Applied Economics 42(7) 1085-100.

Jackson, A.A. 2003. The London railway suburb, 1850-1914, in: Evans, A.K.B. and Gough, J.V. (eds.) The Impact of the Railway on Society in Britain: Essays in Honour of Jack Simmons. Ashgate. Adershot.

Jevons, W.S. 1865. The Coal Question. Macmillan. London.

Jones, C.I. 2011. Life and Growth. NBER Working Papers 17094. National Bureau of Economic Research.

Jones-Lee, M.W., Hammerton, M., Habbott, V., 1983. The value of transport safety: results of a national sample survey. Report to the Department of Transport, University of Newcastle-upon-Tyne, Department of Economics, Newcastle-upon-Tyne.

Kahn, M.E. 2002. Demographic change and the demand for environmental regulation. Journal of Policy Analysis and Management 21(1) 45-62.

Kahn, M.E. 2007. Environmental disasters as risk regulation catalysts? The role of Bhopal, Chernobyl, Exxon Valdez, Love Canal, and Three Mile Island in shaping U.S. environmental law. Journal of Risk and Uncertainty 35(1) 17-43.

Kniesner, T.J., Viscusi, W.K., Ziliak, J.P. 2010. Policy relevant heterogeneity in the value of statistical life: new evidence from panel quantile regressions. Journal of Risk and Uncertainty. 40(1).

Kolstad, C.D. 2006. Interpreting Estimated Environmental Kuznets Curves for Greenhouse Gases. The Journal of Environment and Development 15(1) 42-49.

Krewitt, W. 2002. External costs of energy - do the answers match the questions? Looking back at 10 years of ExternE. Energy Policy. 30, 839-48.

Kristrom, B., Riera, P. 1996. Is the income elasticity of environmental improvements less than one? Environmental and Resource Economics 7(1) 45-55. 
Krupnick, A., Harrison, K., Nickell, N., Toman, M. 1996. The value of health benefits from ambient air quality improvements in Central and Eastern Europe: an exercise in benefits transfer. Environmental and Resource Economics. 7, 307-32.

Landes, D.S. 1969. The Unbound Prometheus: Technological Change and Development in Western Europe from 1750 to the Present. Cambridge University Press. Cambridge.

List J., Gallet C. 1993. The environmental Kuznets curve: Does one size fit all. Ecological Economics. 31, 409-23.

López, R. Mitra, S. 2000. Corruption, pollution, and the Kuznets environment curve. Journal of Environmental Economics and Management 40(2) 137-50.

Luckin, B. 2000. The pollution in the city. In Daunton, M.J. (ed.) The Cambridge Urban History of Britain: 1840-1950. Cambridge University Press. Cambridge.

Maddison, D., Gaarder, M. 2002. Quantifying and valuing life expectancy canges due to air pollution in developing countries, in: Pearce, D.W., Pearce, C. and Palmer, C. (eds) Valuing the Environment in Developing Countries: Case Studies. Edward Elgar. Cheltenham, UK and Northampton, MA, USA.

McConnell, K.E. (1997) Income and the demand for environmental quality. Environment and Development Economics 2(4) 383-399.

McIvor, A., Johnston, R. 2007. Miners' lung: a history of dust disease in British coal mining. Ashgate. Aldershot.

Meadows, D.H., Meadows, D.L., Randers, J., Berhrens, W.H. 1972. The Limits to Growth: A Report to the Club of Rome's Project on the Predicament of Mankind. Universe Books. New York.

Mishan, E.J. 1967. The Costs of Economic Growth. Staples Press. London.

Mitchell, B.R. 1988. British Historical Statistics. Cambridge University Press. Cambridge.

Mosley, S. 2001. The Chimney of the World: A History of Smoke Pollution in Victorian and Edwardian Manchester. The White Horse Press. Brighton.

Mosley, S. 2010. The Environment in World History. Routledge. Abingdon.

Murphy, K.M., Topel, R.H. 2006. The Value of Health and Longevity. The Journal of Political Economy. 114(5), 871-904.

Nordhaus, W.D. 2007. To Tax or Not to Tax: Alternative Approaches to Slowing Global Warming. Review of Environmental Economics and Policy. 1(1), 26-44.

Nordhaus, W.D. 2008. A Question of Balance: Economic Modeling of Global Warming Yale Press. New Haven CT.

Office for National Statistics (2010) GDP. ONS Website. http://www.statistics.gov.uk/

Panayotou, T. 1997. Demystifying the environmental Kuznets curve: Turning a black box into a policy tool. Environment and Development Economics. 2, 465-84. 
Pearce, D.W., Cowards, T. 1995. Assessing Health Costs of Particulate Air Pollution in the UK. CSERGE Working Paper GEC 95-27. Centre for Social and Economic Research on the Global Environment. University of East Anglia and University College London.

Pearson, P.J.G. 1994. Energy, Externalities and Environmental Quality: Will Development Cure the Ills It Creates? Energy Studies Review 6(3) 199-216.

Ray, D., Wang, R. 2001. On Some Implications of Backward Discounting. Department of Economics. New York University. New York.

Registrar General. 1838 onwards. Annual Reports of the Registrars-General of Births, Deaths, and Marriages in England and Wales, 1838-1940. HMSO. London.

Selden T.M., Song, D. 1992. Environmental quality and development: Is there an environmental Kuznet's curve for air pollution? Journal of Environmental Economics and Management. 27, 147-62

Simpson, J. 1962. Chronic bronchitis in England. Journal of Chronic Diseases. 15(10), 991-1000

Smith, V.K., Pattanayak, S.K. Van Houtven, G.L. (2006) Structural benefit transfer: An example using VSL estimates. Ecological Economics. 60, 361-71.

Stern, D.I. 2004. The rise and fall of the Environmental Kuznets Curve. World Development 32(4) 1419-39.

Sterner, T., Persson, U.M. 2008. An even Sterner Review: Introducing relative prices into the discounting debate. Review of Environmental Economics and Policy. 2(1), 61-76.

Supple, B. 1987. The History of the British Coal Industry. Vol. 4. 1914-1946. The Political Economy of Decline. Clarendon Press. Oxford.

Thompson, F.M.L. 1982. The Rise of Suburbia. Leicester University Press. Leicester.

Thorsheim, P. 2006. Inventing Pollution: Coal, Smoke, and Culture in Britain since 1800. Ohio University Press. Athens, Ohio.

Tol, R.S.J. 2002. Estimates of the damage costs of climate change: Part II. Dynamic Estimates. Environmental and Resource Economics. 21, 135-160,

Viscusi, W.K. 2008. How to Value a Life. Journal of Economics and Finance. 32(4), 311-323.

Viscusi, W.K. 2010. Heterogeneity in the the value of statistical life: introduction and overview. Journal of Risk and Uncertainty. 40(1), 1-13.

Viscusi, W.K., Aldy, J.E. 2003. The Value of a Statistical Life: A Critical Review of Market Estimates throughout the World. Journal of Risk and Uncertainty. 27(1), 5-76.

Wolf, C. 1970. The Present Value of the Past. Journal of Political Economy. 78(4/1), 783-792.

Weitzman, C. 2009 On Modeling and Interpreting the Economics of Catastrophic Climate Change. Review of Economics and Statistics. 91(1), 1-19.

Wrigley, E.A., Schofield, R.S. (1981) The population history of England, 1541-1871: a reconstruction. Cambridge University Press. Cambridge. 


\title{
BC3 WORKING PAPER SERIES
}

\author{
Basque Centre for Climate Change (BC3), Bilbao, Spain
}

The BC3 Working Paper Series is available on the internet at the following addresses:

$$
\begin{gathered}
\text { http://www.bc3research.org/lits_publications.html } \\
\underline{\text { http://ideas.repec.org/s/bcc/wpaper.html }}
\end{gathered}
$$

\section{BC3 Working Papers available:}

Roger Fouquet: The Slow Search for Solutions: Lessons from Historical Energy Transitions by Sector and Service Labels: the Case of Dish Washers

Luis M. Abadie, Mikel González-Eguino and José M. Chamorro: Optimal Abandonment of Coal-Fired Stations in the EU

Dirk Rübbelke and Stefan Vögele: Impacts of Climate Change on European Critical Infrastructures: The Case of the Power Sector

Roger Fouquet: The Sustainability of 'Sustainable' Energy Use: Historical Evidence on the Relationship between Economic Growth and Renewable Energy

Karen Pittel and Dirk Rübbelke: Energy Supply and the Sustainability of Endogenous Growth

Ramon Arigoni Ortiz, Alexander Golub, Oleg Lugovoy, Anil Markandya and James Wang: The DICER Model: Methodological Issues and Initial Results.

Elena Ojea, Julia Martin-Ortega and Aline Chiabai: Classifying Ecosystem Services for Economic Valuation: the Case of Forest Water Services forests of Central America Change: A Survey of Recent Quantitative Research 